\title{
THE EFFICACY OF DIFFERENT ORAL MAGNESIUM SUPPLEMENTS FOR MIGRAINE PREVENTION: A LITERATURE REVIEW
}

\author{
Sultan M. Alghadeer
}

\author{
College of Pharmacy - King \\ Saud University \\ Emergency Clinical \\ Pharmacist \\ King Saud University Medical \\ City
}

Submitted: $17-04-2016$

Revised: 22-06-2016

Accepted: 20-08-2016

${ }^{*}$ Corresponding author

Sultan M. Alghadeer

Email:

salghadeer@ksu.edu.sa

\begin{abstract}
No study was conducted to evaluate the efficacy of particular oral magnesium supplement over another in preventing migraine. Different magnesium supplements have different oral absorption and bioavailability. The objective was to identify the efficacy of different oral magnesium supplements in migraine prophylaxis. A literature review using MEDLINE, Scopus, Cochrane library, and EMBASE was conducted during the period from November 1, 2015 until December 30, 2015. Magnesium citrate was used as single oral migraine prophylactic supplement in most of the published trials. Migraine attack frequency and intensity were significantly lower in magnesium citrate group compared to placebo with $41.6-64 \%$ and $43-59 \%$ reduction in migraine attack frequency and severity frequently. Magnesium oxide was used in combination with magnesium citrate in 2 randomized clinical trials (RCTs), and used alone in one RCT in adults and children. No different in migraine frequency or severity between $\mathrm{Mg}$-oxide and placebo in RCT conducted in children while Only Mg-oxide containing groups showed significant reduction in migraine days when compared to control $(p<0.006)$ in RCT conducted in adults. Magnesium chloride had never introduced as migraine prophylactic agent in clinical trials. Magnesium citrate seems to be the preferred oral magnesium supplement for migraine prevention; however, further studies comparing the efficacy of different oral magnesium supplements are needed.
\end{abstract}

Key words: magnesium, migraine, prophylaxis, efficacy, oral supplements

\section{INTRODUCTION}

Magnesium is an important cation in the body that involves in various cellular functions, and plays vital role in maintaining the proper function of skeletal and cardiac muscle (SunEdelstein et al., 2009). Magnesium is also essential mineral in regulating bone metabolism, nerve conduction, muscular contraction, and blood pressure. Deficiency in magnesium level may cause apathy, depression, delirium, seizure, tremors, leg cramps, premenstrual symptoms, and dysarrhythmias.

Although migraine pathogenesis is not completely understood, hypomagnesaemia may lead to increase the frequency of migraine attacks by several mechanisms (Bianchi A et al., 2004). It's believed that migraine pathogenesis is triggered by serotonin receptors, nitric oxide production, and various inflammatory mediators. Magnesium has significant impact on these triggers. A study found that approximately $50 \%$ of patients had low level of intracellular magnesium during their migraine attack (Mauskop et al., 1998). As result, oral magnesium supplements have been introduced as an effective pharmacological intervention for migraine prevention (Guerrera et al., 2009).

Many clinical trials were conducted to evaluate the efficacy of oral magnesium supplements (Facchinetti et al., 1991; Peikert et al., 1996; Pfaffenrath et al., 1996; Demirkaya et al., 2001; Wang et al., 2003; Maizels et al., 2004; Köseoglu et al., 2008; Tarighat et al., 2012; Gaul et al., 2015). Most of these trials showed positive outcomes; however, few studies concluded no difference between oral 


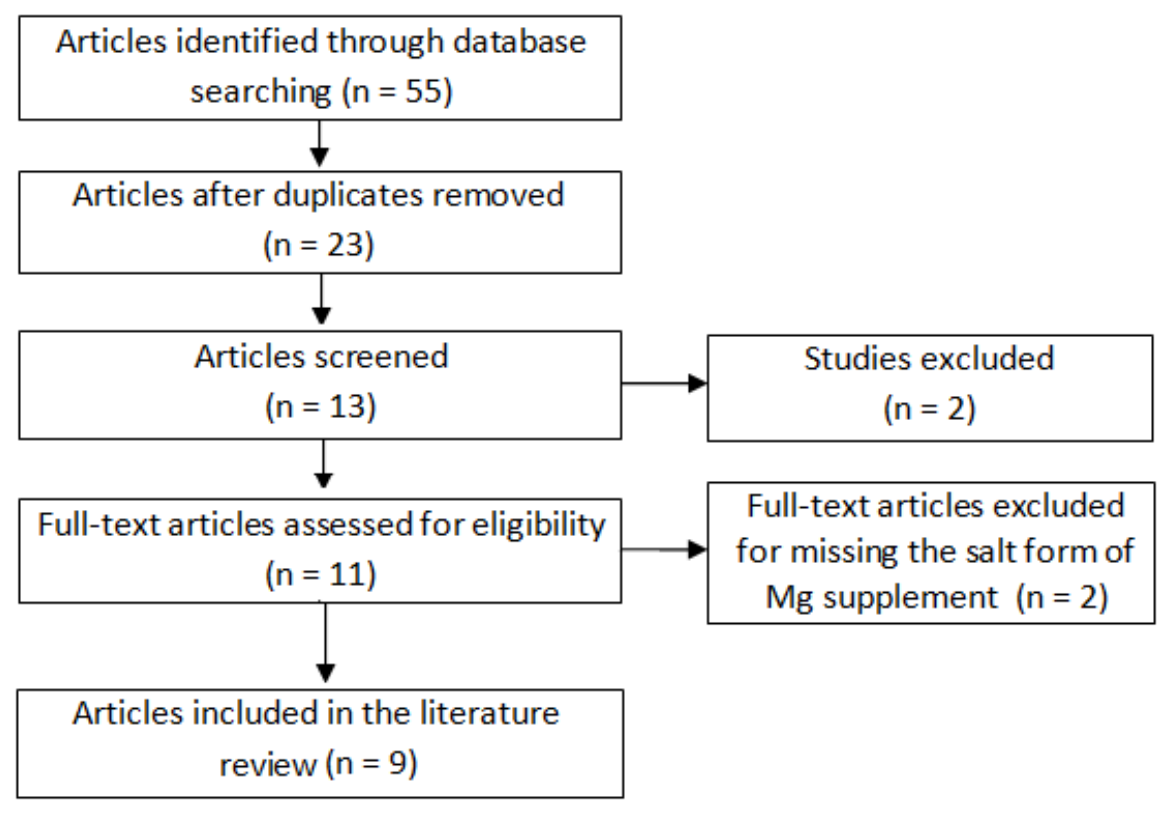

Figure 1. Flowchart of literature review of oral magnesium supplements for migraine prophylaxis

magnesium supplements and placebo. Different salt forms of magnesium forms were used in these studies. Different magnesium supplements have different oral absorption, and therefore different bioavailability. Chemically, the bioavailability of magnesium oxide versus magnesium citrate in healthy individuals is still controversial. Clinically, no study has been conducted to evaluate the efficacy of particular oral magnesium supplement over another in preventing migraine. Therefore, a literature review was conducted to identify the efficacy of different oral magnesium supplements in migraine prophylaxis.

\section{MATERIAL AND METHODS}

A literature review using MEDLINE, Scopus, Cochrane library, and EMBASE was conducted during the period from November 1, 2015 until December 30, 2015. Keywords included migraine, prophylaxis, and magnesium. The search was limited to clinical trials conducted in human subjects, and available in English language. Any experimental human study published thru the period from 1985 till 2015 and evaluated the efficacy of oral magnesium supplements in prevention of migraine attack was included in the review. Studies were excluded if the salt form of magnesium supplement was not mentioned in the study. The quality of randomized clinical trials (RCTs) included in this review was assessed using Jadad score that ranges from 0 to 5 scores. High quality RCTs score 3-5 points on Jadad score while low quality RCTs score 02 points.

\section{RESULTS AND DISCUSSIONS}

A total of 13 articles were screened after removing the duplicated and non-related studies (Figure 1). Eleven articles met the inclusion criteria, and full-text articles were reviewed. Of the reviewed articles, two articles were excluded due to missing naming the magnesium salt, and therefore, 9 RCTs were included in the study. A summary of these RCTs ( Table I). Overall quality of the included RCTs was high, having Jadad score of 5 points in 2 trials and 3 points in 5 trials. Only two RCTs score 2 on Jadad score.

Two RCTs compared the efficacy of magnesium supplements in combination with other supplements to placebo, and two RCTs compared the efficacy of magnesium supplement to active medications and to placebo. 
Table IA. Controlled trials of oral magnesium supplements in migraine prevention.

\begin{tabular}{|c|c|c|}
\hline Trial and methods (score) & Subjects and designa & Diagnosis \& duration of symptoms \\
\hline $\begin{array}{l}\text { Facchinetti et al., } 1991^{5} \\
\text { (3) }\end{array}$ & $\begin{array}{l}\mathrm{n}=35 \text { adults } \\
\text { (age } 28-36 \text { years) } \\
\text { RSBPC }\end{array}$ & Menstrual migraine for $2-9$ years \\
\hline $\begin{array}{l}\text { Peikert et al., } 1996^{6} \\
\text { (3) }\end{array}$ & $\begin{array}{l}\mathrm{n}=81 \text { adults } \\
\text { (age } 18-65 \text { years) } \\
\text { RSBPC }\end{array}$ & $\begin{array}{l}\text { Migraine with or without aura (as defined by } \\
\text { IHS) }\end{array}$ \\
\hline $\begin{array}{l}\text { Pfaffenrath et al., } 1996^{7} \\
\text { (3) }\end{array}$ & $\begin{array}{l}\mathrm{n}=69 \text { adults } \\
\text { (age } 18-60 \text { years) } \\
\text { RDBPC }\end{array}$ & $\begin{array}{l}\text { Migraine without aura for at least } 2 \text { years (as } \\
\text { defined by HIS) }\end{array}$ \\
\hline $\begin{array}{l}\text { Demirkaya et al., } 2000^{8} \\
\text { (3) }\end{array}$ & $\begin{array}{l}\mathrm{n}=87 \text { adults } \\
\text { (age } 20-54 \text { years) } \\
\text { RDBPC }\end{array}$ & $\begin{array}{l}\text { Migraine with or without aura (as defined by } \\
\text { IHS) }\end{array}$ \\
\hline $\begin{array}{l}\text { Wang et al., } 2003^{9} \\
\text { (5) }\end{array}$ & $\begin{array}{l}\mathrm{n}=86 \text { children } \\
\text { (age } 3-17 \text { years) } \\
\text { RDBPC }\end{array}$ & $\begin{array}{l}\text { Headache for at least } \geq 4 \text { weeks accompanied } \\
\text { with anorexia/ nausea, vomiting, photophobia, } \\
\text { sonophobia, a pulsatile or throbbing quality }\end{array}$ \\
\hline $\begin{array}{l}\text { Maizels et al., } 2004^{10} \\
\text { (3) }\end{array}$ & $\begin{array}{l}\mathrm{n}=57 \text { adults } \\
\text { (age } 18-65 \text { years) } \\
\text { RDBPC }\end{array}$ & $\begin{array}{l}\text { Migraine with or without aura for at least } 1 \text { year } \\
\text { (as defined by IHS) }\end{array}$ \\
\hline $\begin{array}{l}\text { Köseoglu et al., } 2008^{11} \\
\text { (2) }\end{array}$ & $\begin{array}{l}\mathrm{n}=40 \text { adults } \\
\text { (age } 20-55 \text { years) } \\
\text { RDBPC }\end{array}$ & $\begin{array}{l}\text { Migraine without aura for at least } 2 \text { years (as } \\
\text { defined by IHS) }\end{array}$ \\
\hline $\begin{array}{l}\text { Esfanjani et al., } 2012^{12} \\
\text { (2) }\end{array}$ & $\begin{array}{l}\mathrm{n}=133 \text { adults } \\
\text { (age } 18-55 \text { years) } \\
\text { RSBPC }\end{array}$ & $\begin{array}{l}\text { Migraine without aura } \\
\text { (as defined by HIS) }\end{array}$ \\
\hline $\begin{array}{l}\text { Gaul et al., } 2015^{13} \\
\text { (5) }\end{array}$ & $\begin{array}{l}\mathrm{n}=130 \text { adults } \\
\text { (age } 18-65 \text { years) } \\
\text { RDBPC }\end{array}$ & $\begin{array}{l}\text { Migraine with or without aura for at least } 1 \text { year } \\
\text { (as defined by IHS) }\end{array}$ \\
\hline
\end{tabular}

The remaining RCTs discussed the effectiveness of magnesium supplement compared to placebo in migraine prophylaxis. All included RCTs were conducted in adults except one RCT that was studied in pediatric population. Different endpoints and follow-up periods were used; however, a three months follow-up of migraine frequency and intensity was the most common used endpoint. Although different doses of magnesium supplements were used in the included RCTs, the $600 \mathrm{mg}$ dose per day seems the common oral dose of magnesium supplement.

\section{Magnesium Citrate}

Magnesium citrate was studied as single prophylactic supplement of migraine with or without aura over 3 months period in adult population in 3 RCTs; 2 of which compared magnesium citrate to placebo and one compared magnesium citrate to placebo and active medications (Peikert et al., 1996; Demirkaya et al., 2001; Köseoglu et al., 2008). Migraine attack frequency and intensity were significantly lower in magnesium citrate group compared to placebo in these RCTs; however, on difference has been shown between magnesium citrate and flunarizine or amitriptyline. Two different doses of magnesium citrate were used; $1830 \mathrm{mg}$ and $600 \mathrm{mg}$ per day. The daily dose of $1830 \mathrm{mg}$ magnesium citrate reduced the migraine attack frequency and severity by $64 \%$ and $59 \%$ compared to $12 \%$ and $7 \%$ with placebo respectively (Demirkaya et al., 2001). The daily dose of $600 \mathrm{mg}$ magnesium citrate reduced the migraine attack frequency by $41.6 \%$ compared to $15.85 \%$ in placebo with no difference in 
Table IB Controlled trials of oral magnesium supplements in migraine prevention.

\begin{tabular}{|c|c|c|}
\hline $\begin{array}{l}\text { Trial and methods } \\
\text { (score) }\end{array}$ & $\begin{array}{l}\text { Treatment drug (Mg } \\
\text { supplement) }\end{array}$ & Control treatment (comparative drugs) \\
\hline $\begin{array}{l}\text { Facchinetti et al., } 1991^{5} \\
\text { (3) }\end{array}$ & MPCA $360 \mathrm{mg}$ daily & $\begin{array}{l}\text { Placebo (participants received MPCA \& } \\
\text { placebo for the first } 2 \text { months, but all } \\
\text { received MPCA in the second } 2 \text { months) }\end{array}$ \\
\hline $\begin{array}{l}\text { Peikert et al., } 19966 \\
\text { (3) }\end{array}$ & $\begin{array}{l}\text { Mg citrate } 600 \mathrm{mg} \text { daily (inform of } \\
\text { trimagnesium dicitrate) }\end{array}$ & Placebo \\
\hline $\begin{array}{l}\text { Pfaffenrath et al., } 1996^{7} \\
\text { (3) }\end{array}$ & MAH 486 mg daily & Placebo \\
\hline $\begin{array}{l}\text { Demirkaya et al., } 2000^{8} \\
\text { (3) }\end{array}$ & Mg citrate $1830 \mathrm{mg}$ daily & $\begin{array}{l}3 \text { comparative groups: } 1 \text { - Flunarizine } 10 \mathrm{mg} \\
\text { daily at night; } 2 \text { - Amitriptyline } 10 \mathrm{mg} \text { daily; } \\
\text { 3- Placebo }\end{array}$ \\
\hline $\begin{array}{l}\text { Wang et al., } 2003^{9} \\
\text { (5) }\end{array}$ & $\mathrm{Mg}$ Oxide $9 \mathrm{mg} / \mathrm{kg}$ daily & Placebo \\
\hline $\begin{array}{l}\text { Maizels et al., } 2004^{10} \\
\text { (3) }\end{array}$ & $\begin{array}{l}\text { Combination of } 300 \mathrm{mg} \mathrm{Mg} \text { oxide } \\
\text { \& citrate (ratio } 1: 1)+400 \mathrm{mg} \\
\text { riboflavin }+100 \mathrm{mg} \text { feverfew daily }\end{array}$ & $\begin{array}{l}\text { Placebo (because riboflavin may cause urine } \\
\text { discoloration, only } 25 \mathrm{mg} \text { riboflavin was } \\
\text { added to placebo to confirm blindness) }\end{array}$ \\
\hline $\begin{array}{l}\text { Köseoglu et al., } 2008^{11} \\
\text { (2) }\end{array}$ & $\mathrm{Mg}$ citrate $600 \mathrm{mg}$ daily & Placebo \\
\hline $\begin{array}{l}\text { Esfanjani et al., } 2012^{12} \\
\text { (2) }\end{array}$ & $\begin{array}{l}3 \text { active groups: } 1-\mathrm{Mg} \text { oxide } 500 \\
\text { mg daily; } 2 \text { - L-carnitine } 500 \mathrm{mg} \\
\text { daily; } 3-\mathrm{Mg} \text { oxide } 500 \mathrm{mg}+\mathrm{L}- \\
\text { carnitine } 500 \mathrm{mg} \text { daily }\end{array}$ & Placebo \\
\hline $\begin{array}{l}\text { Gaul et al., } 2015^{13} \\
\text { (5) }\end{array}$ & $\begin{array}{l}\text { Migravent } \AA \text { (in Germany) or } \\
\text { Dolovent }{ }^{\circledR} \text { (in the USA) + } \\
\text { multivitamins / tracers } \\
\text { - Migravent } \AA \text { (contains } 600 \mathrm{mg} \mathrm{Mg} \\
\text { citrate \& oxide, } 400 \mathrm{mg} \text { riboflavin, } \\
150 \text { coenzyme Q10) } \\
\text { - Dolovent }{ }^{\circledR} \text { (contains } 600 \mathrm{mg} \mathrm{Mg} \\
\text { oxide, } 400 \mathrm{mg} \text { riboflavin, } 150 \\
\text { coenzyme Q10) }\end{array}$ & Placebo \\
\hline
\end{tabular}

migraine severity or duration in a study conducted by Peikert et al. Similar results were shown by Köseoglu et al. who found that the pre/post ratios of migraine attack frequency and severity were 0.55 (45\% reduction) and 0.57 (43\% reduction) in patients who received $600 \mathrm{mg}$ magnesium citrate (Köseoglu et al., 2008).

Magnesium citrate was studied in combination with other supplements to prevent migraine in adults population in 2 RCTs (Maizels et al., 2004; Gaul et al., 2015). In a study conducted by Maizels et al., $300 \mathrm{mg}$ magnesium (1:1 ratio of magnesium citrate and oxide) in combination with riboflavin and feverfew did not show significant difference in reducing the number of migraine attacks over 3 months compared to placebo (Maizels et al., 2004). Similar trial by Gaul et al. who used Migravent ${ }^{\circledR}$ (contains $600 \mathrm{mg} \mathrm{Mg}$ citrate \& oxide, $400 \mathrm{mg}$ riboflavin, 150 coenzyme Q10) in Germany centers and Dolovent ${ }^{\circledR}$ (contains $600 \mathrm{mg} \mathrm{Mg}$ oxide, $400 \mathrm{mg}$ riboflavin, 150 coenzyme Q10) in the United States centers versus placebo found no difference in the migraine days between the treatment and placebo groups; however, the intensity of migraine was lower in Migravent ${ }^{\circledR}$ and Dolovent ${ }^{\circledR}$ compared to placebo. The intensity of migraine was lower in the treatment group 
Table IC. Controlled trials of oral magnesium supplements in migraine prevention.

\begin{tabular}{|c|c|}
\hline $\begin{array}{l}\text { Trial and methods } \\
\text { (score) }\end{array}$ & Outcome measure (follow-up) \\
\hline $\begin{array}{l}\text { Facchinetti et al., } 1991 \\
\text { (3) }\end{array}$ & $\begin{array}{l}\text { At the end of first } 2 \text { months: (1) Duration and intensity of migraine using PTI; } \\
\text { (2) number of migraine days; } \quad \text { (3) incidence of premenstrual symptoms using } \\
\text { MDQ. At the end of second } 2 \text { months: (1) Duration and intensity of migraine } \\
\text { using PTI; (2) incidence of premenstrual symptoms using MDQ }\end{array}$ \\
\hline $\begin{array}{l}\text { Peikert et al., } 1996 \\
\text { (3) }\end{array}$ & $\begin{array}{l}\text { Migraine attach frequency, number of migraine days, migraine severity using } \\
\text { VAS and duration of migraine ( } 12 \text { weeks) }\end{array}$ \\
\hline $\begin{array}{l}\text { Pfaffenrath et al., } 1996 \\
\text { (3) }\end{array}$ & $\begin{array}{l}\geq 50 \% \text { reduction in the duration of migraine in hours or in the intensity of } \\
\text { migraine using VAS ( } 12 \text { weeks) }\end{array}$ \\
\hline $\begin{array}{l}\text { Demirkaya et al., } 2000 \\
\text { (3) }\end{array}$ & $\begin{array}{l}\text { Migraine attack frequency and intensity using pain scale from } 0 \text { "no pain" to } 3 \\
\text { "severe pain" ( } 3 \text { months) }\end{array}$ \\
\hline $\begin{array}{l}\text { Wang et al., } 2003 \\
\text { (5) }\end{array}$ & $\begin{array}{l}\text { The number of headache days reported during the eight } 2 \text {-week intervals of the } \\
\text { study ( } 16 \text { weeks) }\end{array}$ \\
\hline $\begin{array}{l}\text { Maizels et al., } 2004 \\
\text { (3) }\end{array}$ & $\geq 50 \%$ reduction in the number of migraine attacks ( 3 months) \\
\hline $\begin{array}{l}\text { Köseoglu et al., } 2008 \\
\text { (2) }\end{array}$ & $\begin{array}{l}\text { Comparison of } 1 \text { month pre-treatment vs. } 3 \text { months post-treatment in: A- the } \\
\text { frequency \& intensity of migraine attack using VAS in: (1) Mg group, (2) } \\
\text { Placebo group; B- VEP amplitude \& frequency: (1) Mg group (2) Placebo } \\
\text { group; - Comparison of ratio means of pre/post-treatment in clinical and VEP } \\
\text { parameters between Mg group and placebo group }\end{array}$ \\
\hline $\begin{array}{l}\text { Esfanjani et al., } 2012 \\
\text { (2) }\end{array}$ & $\begin{array}{l}\text { - Comparison of } 1 \text { month pre-treatment vs. } 12 \text { weeks post-treatment in the } \\
\text { mean number of migraine attack/month, mean number of migraine days, } \\
\text { migraine severity using pain scale from } 0 \text { "no pain" to } 3 \text { "severe pain" and index; } \\
\text { - Comparison of changes of migraine frequency, severity, or index between } \\
\text { different study groups }\end{array}$ \\
\hline $\begin{array}{l}\text { Gaul et al., } 2015 \\
\text { (5) }\end{array}$ & $\begin{array}{l}\text { Comparing the days with migraine and migraine pain (using HIT- } 6 \text { validated } \\
\text { questionnaire and } 3 \text {-point pain intensity scale) to a } 4 \text { week baseline period ( } 3 \\
\text { months). HIT- } 6 \text { questionnaire included the following items (with their points): } \\
\text { never ( } 6 \text { points), rare ( } 8 \text { points), sometimes ( } 10 \text { points), very often ( } 11 \text { points) } \\
\text { and always ( } 13 \text { points). Headache impact on this scale ranges from } 36 \text { (no } \\
\text { headache) to } 78 \text { (very severe headache); } 3 \text {-point pain intensity scale is rated by } \\
\text { patient as mild, moderate, severe for each migraine day }\end{array}$ \\
\hline
\end{tabular}

compared to placebo with 4.8 points versus 2 points reduction from baseline to the end of the 3 months-therapy in HIT-6 questionnaire $(\mathrm{p}=0.01)$, and with 0.24 points versus 0.06 points reduction from baseline to the end of the 3 months-therapy in 3-point pain intensity scale $(\mathrm{p}=0.03)$ (Gaul et al., 2015).

\section{Magnesium Oxide}

Magnesium oxide was studied as single prophylactic supplement of migraine in 2 RCTs (Wang et al., 2003; Tarighat et al., 2012). A study conducted by Wang et al. in pediatric population (age 3-17 years) over 16 weeks found no difference in the number of headache days between magnesium group (magnesium oxide $9 \mathrm{mg} / \mathrm{kg} /$ day) and placebo group; however, the frequency of headache was significantly lower in magnesium group over time (Wang et al., 2003).

Another trial by Esfanjani et al. compared the efficacy of magnesium oxide (500mg/day), L-carnitine (500mg/day), and combination of magnesium oxide and Lcarnitine to placebo in prevention of migraine attack in adult population over 12 weeks. The first endpoint was to compare 1 month pre-treatment versus 12 weeks post-treatment for each study group individually in the followings: (1) the mean number of migraine 
Table ID. Controlled trials of oral magnesium supplements in migraine prevention.

\begin{tabular}{|c|c|}
\hline $\begin{array}{l}\text { Trial and methods } \\
\text { (score) }\end{array}$ & Results: drug vs. control \\
\hline $\begin{array}{l}\text { Facchinetti et al., } 1991 \\
\text { (3) }\end{array}$ & $\begin{array}{l}\text { - At the end of first } 2 \text { months: PTI lower in MPCA group }(\mathrm{p}<0.03) \text {; Significant } \\
\text { reduction in migraine days in MPCA group }(\mathrm{p}<0.01) \text {; Significant decrease in } \\
\text { MDQ in MPCA group }(\mathrm{p}<0.05) \text {; - At the end of second } 2 \text { months: Significant } \\
\text { decrease in PTI \& MDQ since all participants received MPCA during this period }\end{array}$ \\
\hline $\begin{array}{l}\text { Peikert et al., } 1996 \\
\text { (3) }\end{array}$ & $\begin{array}{l}\text { - Frequency of attack reduced by } 41.6 \% \text { in } \mathrm{Mg} \text { group vs. } 15.8 \% \text { in placebo group } \\
(\mathrm{p}<0.05) \text {; - Number of days with migraine reduced by } 50.3 \% \text { in } \mathrm{Mg} \text { group vs. } \\
21.2 \% \text { in placebo group }(\mathrm{p}<0.05) \text {; - No sig differences in migraine severity or } \\
\text { duration }\end{array}$ \\
\hline $\begin{array}{l}\text { Pfaffenrath et al., } 1996 \\
\text { (3) }\end{array}$ & $10(28.6 \%)$ vs. $10(29.4 \%) . \mathrm{P}$ value $=0.6599$ \\
\hline $\begin{array}{l}\text { Demirkaya et al., } 2000 \\
\text { (3) }\end{array}$ & $\begin{array}{l}\mathrm{Mg} \text { citrate, flunarizine and amitriptyline were all superior to placebo }(\mathrm{p}<0.001) \text { in } \\
\text { reducing both attack frequency and severity; neither drug was superior to the } \\
\text { other }\end{array}$ \\
\hline $\begin{array}{l}\text { Wang et al., } 2003 \\
\text { (5) }\end{array}$ & $\begin{array}{l}\text { The headache frequency over time was significantly lower in } \mathrm{Mg} \text { group ( } \mathrm{P} \\
=0.037) \text { than in placebo }(\mathrm{P}=0.086) \text {, but no difference between } \mathrm{Mg} \& \text { placebo at } \\
\text { the end of the study }(\mathrm{P}=0.88)\end{array}$ \\
\hline $\begin{array}{l}\text { Maizels et al., } 2004 \\
\text { (3) }\end{array}$ & $\begin{array}{l}10(42 \%) \text { vs. } 11(44 \%) \\
\mathrm{P} \text { value }=0.87\end{array}$ \\
\hline $\begin{array}{l}\text { Köseoglu et al., } 2008 \\
\text { (2) }\end{array}$ & $\begin{array}{l}\text { - A(1) frequency } 3 \text { vs. } 2(\mathrm{p}<0.001) \text {; intensity } 7.57 \text { vs. } 4(\mathrm{p}<0.001) ;-\mathrm{A}(2) \\
\text { frequency } 3 \text { vs. } 3.5(\mathrm{p}<0.05) \text {; intensity not significant }(\mathrm{p}>0.05) ;-\mathrm{B}(1) \&(2) \\
\text { Only VEP amplitude was sig lower in } \mathrm{Mg} \text { group } 5.98 \text { vs. } 5.62(\mathrm{p}<0.05) ;- \text { All } \\
\text { ratios were sig lower in } \mathrm{Mg} \text { group }(\mathrm{p}<0.05) \text {, except with VEP latency }(\mathrm{p}>0.05)\end{array}$ \\
\hline $\begin{array}{l}\text { Esfanjani et al., } 2012 \\
\text { (2) }\end{array}$ & $\begin{array}{l}\text { All } 4 \text { study groups showed significant decrease in the number of migraine attacks } \\
\text { and days, severity and index before \& after treatment }(\mathrm{p}<0.05) \text {; All } 4 \text { study } \\
\text { groups showed significant reduction in the number of migraine attack only ( } \mathrm{p}= \\
0.008) \text {. Only } \mathrm{Mg} \text { groups showed significant reduction in migraine days when } \\
\text { compared to control }(\mathrm{p}<0.006)\end{array}$ \\
\hline $\begin{array}{l}\text { Gaul et al., } 2015 \\
\text { (5) }\end{array}$ & $\begin{array}{l}\text { Migraine reduced by } 1.8 \text { days/month in treatment group and by one day/month } \\
\text { in the placebo group ( } \mathrm{p}=0.23 \text { ); The intensity of migraine was lower in the } \\
\text { treatment group compared to placebo with } 4.8 \text { points versus } 2 \text { points reduction } \\
\text { from baseline to the end of the } 3 \text { months-therapy in HIT- } 6 \text { questionnaire ( } \mathrm{p}= \\
0.01 \text { ), and with } 0.24 \text { points versus } 0.06 \text { points reduction from baseline to the end } \\
\text { of the } 3 \text { months-therapy in } 3 \text {-point pain intensity scale }(\mathrm{p}=0.03 \text { ) }\end{array}$ \\
\hline
\end{tabular}

HIT $=$ headache impact test; IHS = international headache society; $\mathrm{MAH}=$ magnesium aspartate hydrochloride; MDQ = Moos Menstrual Distress Questionnaire; Mg = magnesium; MPCA = Magnesium pyrrolidone carboxylic acid; PTI = Pain Total Index; RDBPC = randomized double blind placebo controlled; VAS $=$ visual analog scale; $\mathrm{VEP}=$ visual evoked potential study

attack per month; (2) the mean number of migraine days per month; (3) severity using pain scale from 0 "no pain" to 3 "severe pain" and index; and (4) serum level of magnesium and Lcarnitine determine. The second objective was to compare changes of migraine attacks or days per month, severity, or index between different study groups. All the four study groups showed significant decrease in the number of migraine attacks and days, severity and index before \& after treatment $(p<0.05)$. Also all the four study groups showed significant reduction in the number of migraine attack only $(p=0.008)$, but only Mg groups showed significant reduction in migraine days when compared to control $(p<0.006)$, but notin migraine severity or index. 


\section{Other oral magnesium supplements}

Pfaffenrath et al. evaluated the efficacy of 486 mg magnesium aspartate hydrochloride (MAH) in reducing the duration or intensity of migraine compared to placebo in adult population over 12 weeks (Pfaffenrath et al., 1996). No difference between the MAH and placebo in the primary endpoints. Magnesium pyrrolidone carboxylic acid (MPCA) is another magnesium supplement used in trial conducted by Facchinett et al. in women with menstrual migraine. ${ }^{[5]}$ Participants were given either 360 $\mathrm{mg}$ of MPCA per day or placebo for the first 2 months, and all participants then received MPCA for the second 2 months. The primary endpoints were intensity and duration of migraine using Pain Total Index (PTI), number of migraine days, and incidence of premenstrual symptoms using Moos Menstrual Distress Questionnaire (MDQ) at the end of the first 2 months. Both MPCA and placebo showed a significant reduction in PTI $(\mathrm{p}<0.03)$; however, only MPCA showed a significant reduction in MDQ $(\mathrm{p}<0.05)$ at the end of the first 2 months. Also, MCPA group was associated with lower migraines days with significant reduction in number of migraine days from $4.7 \pm 3.1$ to $2.4 \pm 2.2$ ( $p<0.01)$.

Although the clinical superiority of a particular oral magnesium supplement in prevention of migraine is not determined yet, the absorption and bioavailability of three forms of magnesium (citrate, oxide, and amino acid chelate), each contains $300 \mathrm{mg}$ elemental magnesium, were compared to placebo by Walker et al. in RCT including healthy participants for 2 months (Walker et al., 2003). Any participant with disease, condition, or medication that may alter the absorption of magnesium was excluded. After 2 months of the study, magnesium citrate showed a significant increase in urine excretion ( $p=$ $0.033)$, saliva concentration $(p=0.027)$, and plasma concentration $(\mathrm{p}=0.006)$ compared to magnesium oxide or placebo, but no difference in red blood cell magnesium concentration between the three forms. As result, magnesium citrate was concluded to be more bioavailable than other magnesium preparations. In contrast, magnesium oxide showed significant increase in intracellular magnesium concentration $(p<0.001)$ and significant decrease in LDL cholesterol ( $\mathrm{p}=0.042$ ) compared with magnesium citrate in a crossover RCT conducted by Shechter et al. in healthy individuals (Shechter et al., 2012).

Clinically, there is no clinical trial compared the efficacy of particular oral magnesium supplement against another in prevention of migraine, instead different magnesium supplements were studied against placebo. Magnesium citrate seems to be the effective choice in preventing migraine in adult population based on the reviewed articles. In addition, the results of Taubert's RCT (article in Germany) showed a significant reduction in migraine attack after administering his subjects $600 \mathrm{mg}$ magnesium citrate (in form of trimagnesium dicitrate) (Taubert, 1994). However, neither magnesium citrate nor magnesium oxide were able to improve blood pressure, fasting glucose or $\mathrm{H}_{1} \mathrm{Ac}$ level in diabetic patients (Song et al., 2006).

Magnesium chloride was claimed to be more bioavailable than other commercial magnesium preparations, even though it had never been studied as migraine prophylactic agent (Firoz et al., 2001). However; magnesium chloride showed a significant reduction in blood pressure compared to placebo in 2 RCTs (Guerrero-Romero et al., 2009; Shafique et al., 1993).

Many of the included studies are old and thereby quality of these articles is questionable; however, the literature review was conducted to answer very specific question that necessities the exclusion of some studies. Another limitation is the usage of different outcome measures for migraine frequency or severity. Furthermore, there is inconsistency in the usage doses of particular oral magnesium supplement and in migraine characteristics.

\section{Gaps between guidelines and practice}

Although of the low quality evidence, Canadian Headache Society strongly recommends magnesium citrate $600 \mathrm{mg}$ per day as migraine prophylactic agent (Hui et al., 2003). It's the only organization that recommends particular magnesium supplement and its dose. The other organizations such as the American Academy of Neurology and the American Headache Society did not specify the type of oral magnesium supplement; however, they 
relied on the same trials that Canadian Headache Society used for their recommendations (Silberstein et al., 2012). In the practice, the available magnesium supplement, regardless of the type of it salt, is introduced as migraine prophylactic agent.

\section{CONCLUSION}

Magnesium citrate was used as single oral migraine prophylactic supplement in most of the published trials. Magnesium oxide was used in combination with magnesium citrate in 2 RCTs, and used alone in one RCT in adults and pediatric population. Magnesium chloride had never introduced as migraine prophylactic agent in the clinical trials. Therefore, Magnesium citrate seems to be the preferred oral magnesium supplement for migraine prevention at the mean time; however, further studies comparing the efficacy of different oral magnesium supplements are needed to identify the gap between guidelines and practice regarding the use of oral magnesium supplements for migraine prevention.

\section{REFERENCES}

Sun-Edelstein C, Mauskop A. Role of magnesium in the pathogenesis and treatment of migraine. Expert Rev Neurother. 2009; 9(3):369-379.

Bianchi A, Salomone S, Caraci F, Pizza V, Bernardini R, D'Amato CC. Role of magnesium, coenzyme Q10, riboflavin, and vitamin $\mathrm{B} 12$ in migraine prophylaxis. Vitam Horm. 2004; 69:297-312.

Mauskop A, Altura BM. Role of magnesium in the pathogenesis and treatment of migraines. Clin Neurosci. 1998; 5(1):24-27.

Guerrera MP, Volpe SL, Mao JJ. Therapeutic uses of magnesium. Am Fam Physician. 2009; 80(2):157-162.

Facchinetti F, Sances G, Borella P, Genazzani AR, Nappi G. Magnesium prophylaxis of menstrual migraine: effects on intracellular magnesium. Headache. 1991; 31(5):298-301.

Peikert A, Wilimzig C, Köhne-Volland R. Prophylaxis of migraine with oral magnesium: results from a prospective, multi-center, placebo-controlled and double-blind randomized study. Cephalalgia an Int J beadache. 1996;
16(4):257-263.

Pfaffenrath V, Wessely P, Meyer C, et al. Magnesium in the prophylaxis of migraine--a double-blind placebocontrolled study. Cephalalgia. 1996; 16(6):436-440.

Demirkaya S, Dora B, Topcuoglu MA, Vural $\mathrm{O}$, U HU. A comparative study of magnesium, flunarizine and amitriptyline in the prophylaxis of migraine. J Headache Pain. 2001; 1(2000):179-186.

Wang F, Van Den Eeden SK, Ackerson LM, Salk SE, Reince RH, Elin RJ. Oral magnesium oxide prophylaxis of frequent migrainous headache in children: A randomized, double-blind, placebo-controlled trial. Headache. 2003; 43(6):601-610.

Maizels M, Blumenfeld A, Burchette R. A combination of riboflavin, magnesium, and feverfew for migraine prophylaxis: A randomized trial. Headache. 2004; 44:885890.

Köseoglu E, Talaslioglu A, Gönül AS, Kula M. The effects of magnesium prophylaxis in migraine without aura. Magnes Res. 2008; 21(2):101-108.

Tarighat Esfanjani A, Mahdavi R, Ebrahimi Mameghani M, Talebi M, Nikniaz Z, Safaiyan A. The Effects of Magnesium, 1Carnitine, and Concurrent Magnesium-1Carnitine Supplementation in Migraine Prophylaxis. Biol Trace Elem Res. 2012; 150(1-3):42-48.

Gaul C, Diener H-C, Danesch U. Improvement of migraine symptoms with a proprietary supplement containing riboflavin, magnesium and Q10: a randomized, placebo-controlled, double-blind, multicenter trial. J Headache Pain. 2015; 16(1):32.

Walker AF, Marakis G, Christie S, Byng M. Mg citrate found more bioavailable than other $\mathrm{Mg}$ preparations in a randomised, double-blind study. Magnes Res. 2003; 16(3):183-191.

Shechter M, Saad T, Shechter A, Koren-Morag $\mathrm{N}$, Silver BB, Matetzky S. Comparison of magnesium status using $\mathrm{X}$-ray dispersion analysis following magnesium oxide and magnesium citrate treatment of healthy subjects. Magnes Res. 2012; 25(1):28-39. 
Taubert K. [Magnesium in migraine. Results of a multicenter pilot study]. Fortschr Med. 1994; 112(24):328-330.

Song Y, He K, Levitan EB, Manson JE, Liu S. Effects of oral magnesium supplementation on glycaemic control in Type 2 diabetes: a meta-analysis of randomized double-blind controlled trials. Diabet Med. 2006; 23(10):10501056.

Firoz M, Graber M. Bioavailability of US commercial magnesium preparations. Magnes Res. 2001; 14(4):257-262.

Guerrero-Romero F, Rodríguez-Morán M. The effect of lowering blood pressure by magnesium supplementation in diabetic hypertensive adults with low serum magnesium levels: a randomized, doubleblind, placebo-controlled clinical trial. $J$ Hum Hypertens. 2009; 23(4):245-251.

Shafique M, Misbah-ul-Ain, Ashraf M. Role of magnesium in the management of hypertension. J Pak Med Assoc. 1993; 43(4):77-78.

Hui ACF, Boet R, Cheng C a Y. Canadian Journal of Neurological Sciences. Spontaneous extra-cranial Vertebr artery dissection. 2003; 30:150-151.

Silberstein SD, Holland S, Freitag F, Dodick DW, Argoff C, Ashman E. Evidencebased guideline update: pharmacologic treatment for episodic migraine prevention in adults. Neurology. 2012; 78(17):1337-1345. 